\title{
Utopioiden arkipäivää
}

\author{
Riikka Haapalainen
}

Riikka Haapalainen, Utopioiden arkipäivää: Osallistumisen ja muutoksen paikkoja nykytaiteessa 1980-2011 (Helsingin yliopisto, 2018). https:!/hel-: da.helsinki.fi/handle/10138/229855.

\section{LEKTIO.}

Arvoisa kustos, kunnioitettu vastaväittäjä, hyvät kuulijat,

"Aber etwas fehlt (Mutta jotain puuttuu)", hokee Paul Ackermann Bertolt Brechtin käsikirjoittamassa Mahagonny-kaupungin nousu ja tuho -oopperasatiirissa vuodelta 1930. Alaskalainen metsuri Ackermann on saapunut ystävineen autiomaan keskelle perustettuun Mahagonnyn ihmeelliseen kaupunkiin. Kaupunki lupaa kaikille kaikkea, mitä rahalla vain voi saada. Sieltä on kaikki kiellot poistettu. Mutta jotain puuttuu. Mahagonnyn ostetut nautinnot saavat Ackermannin kaipaamaan jotain muuta.

Ackermannin "jotain puuttuu" -lause on ollut myös väitöstutkimukseni Utopioiden arkipäivää. Osallistumisen ja muutoksen paikkoja nykytaiteessa 1980-2011 esittämän utopian ajatuksen lähtökohtana. Tutkimuksessani tarkastelen osallistavan taiteen arjen muutosta ja suhteita luovia sisältöjä, jotka voidaan ymmärtää myös utooppisina.

Tutkimusaineistoni muodostavat kuusi nykytaiteen teosta, joilla on keskenään hyvin erilainen suhde osallistumiseen: ranskalaisen Sophie Callen Suite vénitienne (Venetsialainen sarja, 1980), yhdysvaltalaisen John Baldessarin Your Name in Lights (Sinun nimesi valoissa, 2011), suomalaisen Minna Heikinahon IImainen aamiainen (1994), tanskalaisen Superflex-taiteilijaryhmän Free Shop (IImainen kauppa -interventio, jota on toteutettu vuodesta 2003 alkaen), Copenhagen Free University (Kööpenhaminan vapaa yliopisto, CFU, joka toimi vuosina 2001-2007) sekä belgialaissyntyisen Francis Alÿsin When Faith Moves Mountains (Kun usko siirtää vuoria, 2002). Lisäksi palaan tarkastelussani säännöllisesti 1900-luvun alun eurooppalaisen avantgardetaiteen toimintastrategioihin ja 1960-luvun taiteen kokeelliseen ilmapiiriin.

Nämä kuusi esimerkkiteosta ovat suunnanneet ajattelemaan itseään niiden urbaanien tapahtumapaikkojen kautta. Siksi teosluentojeni pohjana ovat tutut ja tavalliset julkiset kaupunkitilat: katu, kahvila, kauppa, koulu ja katedraali. Arkinen jokapäivä kytkeytyy näihin paikkoihin niiden vahvassa sosiaalisessa ja toiminnallisessa ennakoivuudessa. Ainoastaan teosten tuoma jokin katkaisee arjen tavanomaisen kulun. Tietämättään tai tarkoituksella teosprosesseihin osallistuessaan inmiset irrottautuvat arjen rutiineistaan ja jo valmiiksi käsikirjoitetuista rooleistaan. Tällöin taide toimii lähetteenä, jossa mahdollistuu nykyhetken kritiikki - toisin näkeminen ja vaihtoehtojen löytäminen - utopia. 
"Jotain", oli lapseni tyypillinen vastaus päiväkoti-ikäisenä, kun häneltä esimerkiksi kysyttiin, mitä päivän aikana oli tapahtunut. Välttelevä ja kohdentumaton "Jotain" tavoittaa epämääräisyydessään arjen moninaisuuden: jotain sisältää paljon ja kaikenlaista ilman erityisiä huippukohtia tai -hetkiä. On vain "jotain", jota ei suoraan sanoiksi tavoita.

"Jotain" sopii myös kuvaamaan monia tutkimukseni osallistavan taiteen prosesseja. Kokemukset ja tulkinnat teoksista ovat hajautuneita. Niitä on mahdoton tavoittaa selkeinä ja selväpiirteisinä. Osallistavalta taiteelta puuttuukin usein selkeä muoto ja teosluonne, minkä takia sitä on pidetty haasteellisena kritiikille ja käsitteellistämiselle. Tutkimuksessani kutsun osallistavan taiteen hajautunutta, pirstalemaista muotoa transsituationaaliseksi, ylipaikallistuneeksi.

Ylipaikallistuneina teosten vastaanotto ei koskaan voikaan olla kattava, kokonainen tai lopullinen: niiltä puuttuu keskiö. Aina jotain teoksesta jää tavoittamatta. Siksi niitä voi tarkastella ainoastaan prosesseina: suhteina ja kytköksinä johonkin muuhun. Teosten tarkastelussa tämä on merkinnyt sitä, että en ole 'tulkinnut' tai 'analysoinut' teoksia, vaan kirjoittanut ne uudelleen tähän erityiseen tutkimukselliseen yhteyteen. Olen pyrkinyt harjoittamaan teosluentaa, joka ei sopeuttaisi tai hegemonisoisi kohdettaan. Epämääräinen on saanut osin jäädäkin hankalasti epämääräiseksi, joksikin.
Aloitan tutkimukseni 1800-luvun modernin elämän sankarin, flâneurin, tavoin kaupungin kaduilta.

Pohdin 'katua' arjen julkisena toteutumispaikkana kahden hyvin erilaisen teoksen ja kaupunkirakenteen kautta: Suite vénitiennen tapahtumapaikan, Venetsian keskiaikaisten katujen ja kujien, labyrinttimäisyys rinnastuu Your Name in Lightsin esittämispaikkojen, Sydneyn, Amsterdamin ja Pariisin moderniin ja kaupalliseen katutilaan.

Ensimmäinen teosesimerkkini vie vuoteen 1980 ja Venetsiaan. Noina aikoina Sophie Callella oli kotikaupungissaan Pariisissa ollut tapana valita väkijoukoista sattumanvaraisesti joku, jota lähteä seuraamaan. Calle myös kuvasi seurattaviaan salaa ja kirjasi heidän liikkeitään - kunnes kadotti heidät.

Sitten sattumalta, eräillä kutsuilla Calle joutui kasvokkain miehen kanssa, jota oli juuri samana päivänä varjostanut. Calle kuulee mieheltä, Henri B:Itä, että tämä on piakkoin matkustamassa Venetsiaan. Calle päättää jatkaa miehen seuraamista Venetsiaan. Mukaansa hän pakkaa muun muassa vaalean peruukin, meikkejä, aurinkolaseja ja kameran. Suite vénitienne - venetsialainen sarja - alkaa.

Suite vénitienne on Sophie Callen tarina kahdesta viikosta, jotka hän vietti Venetsiassa Henri B:n jäljillä. Teos koostuu Callen päiväkirja- ja karttamerkinnöistä sekä mustavalkoisista valokuvista, joihin Calle on jäl- jittäessään Henri B:n jalanjälkiä tallentanut kaupungin katuja, kylttejä ja kahviloita sekä kohtaamiaan inmisiä. Lopulta kuvasarja täydentyy myös kuvilla Henri B:stä.

Suite vénitiennen tulkinnoissa on tyypillisesti kiinnitytty Sophie Callen ja Henri B:n väliseen suhteeseen; paljastumisen pelkoon ja lopulta paljastumisen vääjäämättömyyteen. Teosta ei ole nähty osallistavana. Silti osallistumisen näkökulmasta kiinnostavaa on, kuinka Callen jäljittelyprosessi tuo esiin venetsialaista kaupunkiarkea kannattelevat huomaamattomat sosiaaliset ja aineelliset liitokset. Jäljittäessään Henri B:tä taiteilija tarvitsee avukseen lukuisia "liittolaisia", hotellivirkailijoita, tuttujen tuttuja, matkamuistokauppiaita ja niin edelleen. Näistä "liittolaisista" muotoutuu teoksen yhteisö, sen toimijat ja osakkaat. Yhteisöä ei etsitä tai nimetä. Se tulee esiin Callen ongelmanratkaisun prosessissa.

John Baldessarin teos Your Name in Lights on tutkimukseni teoksista ainut, johon olen itsekin osallistunut (kuva 1). Olin saanut sähköpostiini mainoksen, jossa luvattiin minulle ja tuttavilleni kuuluisuutta. Nimelleni tarjottiin viidentoista sekunnin mainostilaa neonvalojen loisteessa, ja aivan ilmaiseksi. Tartuin tarjoukseen ja ilmoittauduin mukaan. Ja niin myöhemmin seurasin nettilähetystä toiselta puolelta maapalloa, jossa näytettiin kuinka Australian Museumin julkisivuun Sydneyssä ilmestyi oma, säihkyvä nimeni. 


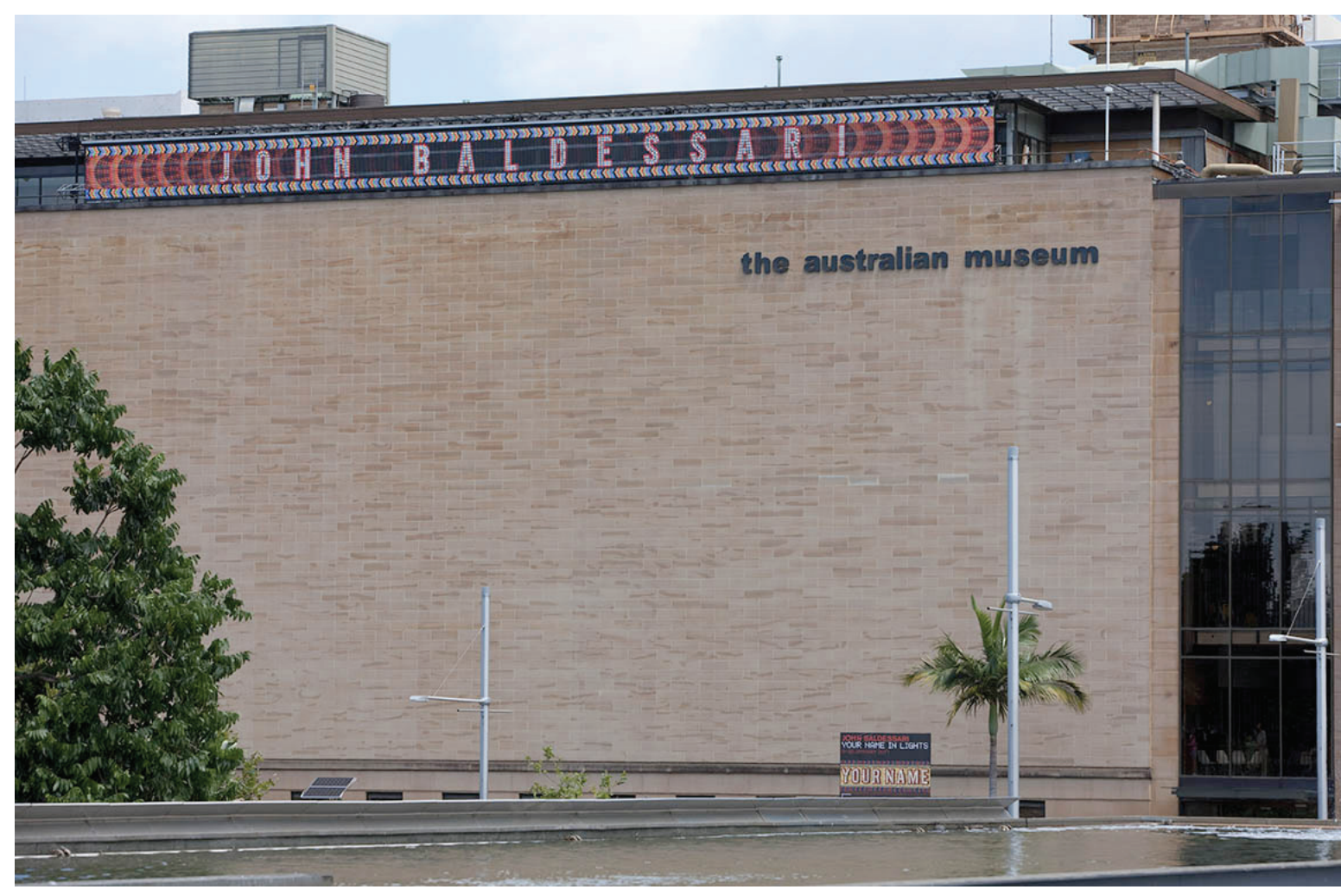

Kuva 1. Kaldor Public Art Project 23: John Baldessari 2011. Your Name in Lights, Australian Museumin julkisivu, Sydney, 8.-30.1.2011. Kuva: Paul Green.

Tähtihetkeni kesti luvatut viisitoista sekuntia. Minulla nämä sekunnit kuluivat siihen, että yritin ottaa nimestäni mahdollisimman näyttävän kuvakaappauksen Silti, tänään ette näe nimeäni valoissa. Olen kadottanut kuvan. Sen sijaan tässä on ilotulitusten ja riemunkiljahdusten kera virallisia kuvia teoksen avajaisista

\section{Sydneystä (kuva 2).}

John Baldessarin Your Name in Lights -teos on siis rakennuksen julkisivuun kiinnitettävä kolmekymmentä metriä pitkä led-valokyltti. Näihin valoihin voi jokainen, niin halutessaan, saada nimensä loistamaan osana teosta.
Kuva 2. Kaldor Public Art Project 23: John Baldessari 2011. Your Name in Lights, Australian Museumin julkisivu, Sydney, 8.30.1.2011. Kuva: Paul Green.

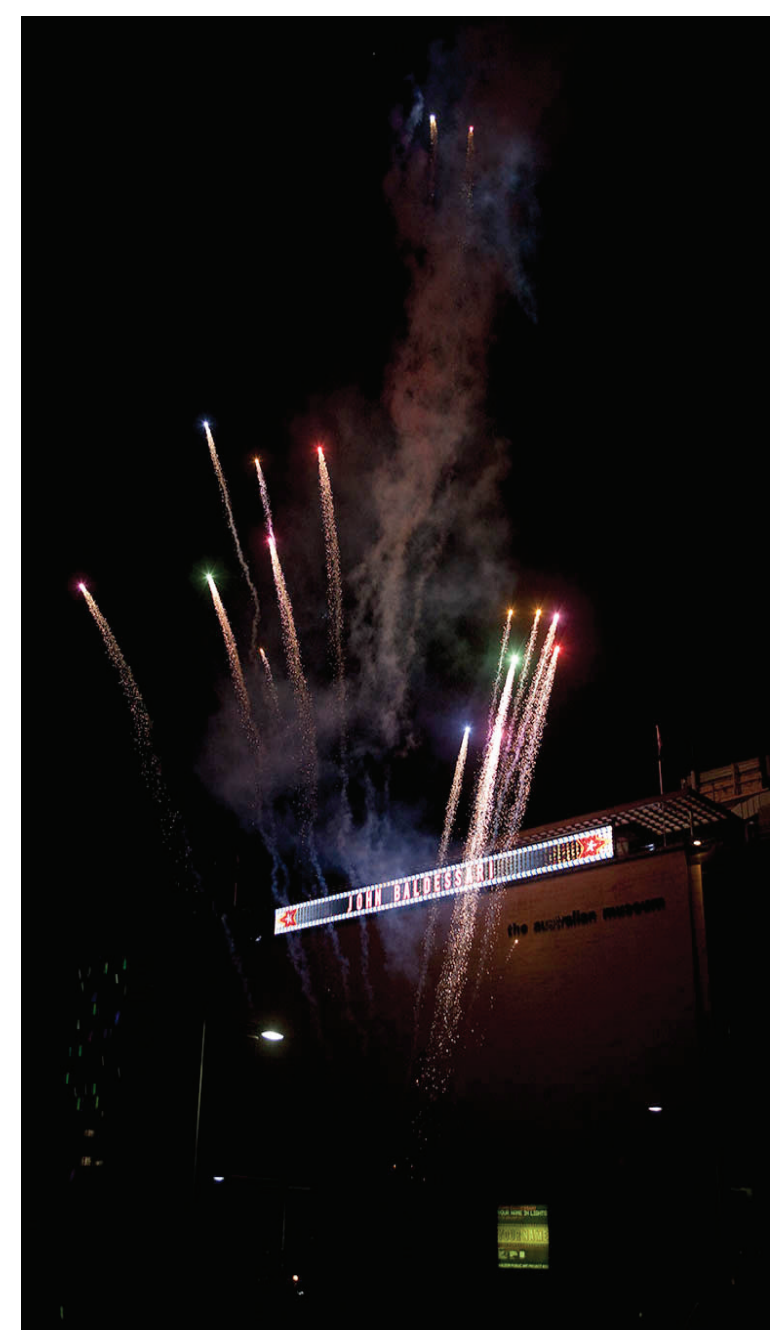


Yksi mahdollinen luentamalli näille viidentoista sekunnin välein vaihtuville nimille on tarkastella niitä käsitetaiteelle tyypillisinä listoina tai luetteloina. Minut teoksen tarjoama innostunut noste ja sitä seurannut nopea antikliimaksi sai pohtimaan sen synnyttämää yhteisöllisyyttä ja suhdetta katutilan kaupallistumiseen ja tapahtumallistumiseen. Tässä tarkastelussa teoksen ehdottama muutos jää kapeaksi: se kiinnittää osallistujansa siihen minkä jo tuntee ja jo tietää. Se vahvistaa niitä sisältöjä ja kytköksiä, joita jo on.

On helppo kuvitella, että Your Name in Lights -teoksen kaltaiset spektaakkelimaiset neonvalot olisivat voineet loistaa Bertolt Brechtin kuvaileman Mahagonny-kaupungin kaduilla; kaupungin, jossa kilpaillaan ihmisten huomiosta ja rahasta. Sen sijaan tässä
Kuva 3. Superflex 2011. Free Shop (Levykauppa Digelius, Helsinki). Kuva: IHME-nykytaidefestivaali/Veikko Somerpuro.

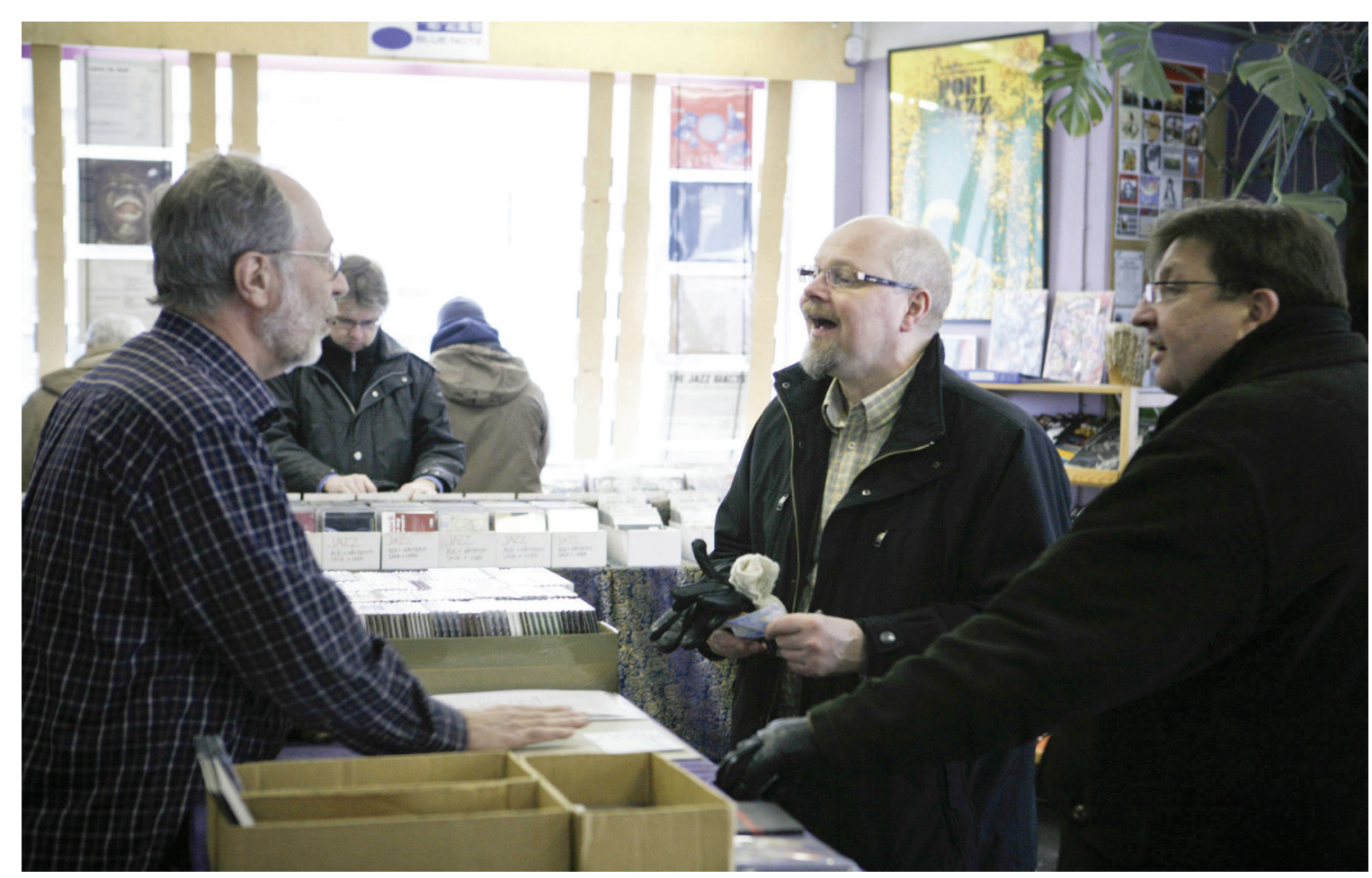

kuvassa oleva kahvila ei huomioarvosta kilpaile. Sen tunnistaa kahvilaksi vain ikkunaan kiinnitetystä oranssista lapusta, jossa lukee ilmainen aamiainen / free breakfast sekä aukioloajat. Kyse on Minna Heikinahon IImainen aamiainen -teoksesta.

Heikinaho avasi ilmaisen aamiaishuoneensa tyhjäksi jääneeseen liiketilaan Helsingin Hakaniemeen lamakesänä 1994. Ajankohtaisuutensa vuoksi IImaisesta aamiaisesta tuli nopeasti sen hetken puhutuin yhteisötaiteen teos Suomessa. Lähellä sijaitsevien Pelastusarmeijan leipäjonojen tavoin Heikinahon aamiaistilan arki näytti laman konkreettiset seuraamukset. Ihmisillä oli vaikeuksia saada rahat riittämään ruokaan ja elämiseen. Silti ilmainen aamiaishuone ei ollut vain paikka, jossa tarjottiin ilmaista ruokaa nälkäisille. Se oli radikaalin vieraanvarainen paikka, joka kokosi erilaisia ja eritaustaisia ihmisiä yhteen, saman ruokapöydän äärelle.

IImainen aamianen toi näkyviin julkisen seurallisuuden sekä sen kääntöpuolen, toisista eriytyneen yksinäisyyden - eriarvoistuneen kaupunkitilan.

Tutkimuksessani pohdin teoksen ehdottamaa julkista yhdessäoloa tuntemattomien kesken ja mietin, minkälaisia asioita tai ilmiöitä ilmaiseksi tarjottu aamiainen tekee osallistujilleen ja osallistujissaan näkyviksi.

Olen tyypillisesti kirjoittanut tutkimukseni teosesimerkit tarinan muotoon. Onhan tarina toimiva, vaikka 
myös kyseenalaistettu tapa jäsentää kokemuksia.

Osallistavan taiteen tarina voi kulkea esimerkiksi

tähän tapaan: teet normaaliin tapaan ostoksia kaupassa, joka tällä kertaa voisi olla vaikka levykauppa (kuvat 3 ja 4 ). Mahdollisesti tutustut levyvalikoimaan selailet uutuuksia ja punnitset mielessäsi omia musiikkitoiveitasi ja -tarpeitasi. Lopulta valitset levyn ja siirryt sen kanssa kassalle. Niin kuin aina. Ostosten tekoon liittyviä toimintoja ja vuorosanoja ei juuri tarvitse miettiä tai kyseenalaistaa. Kunnes pasmat menevät sekaisin. Myyjän ojentamassa kassakuitissa lukee, etteivät ostokset maksa mitään. Kuittiin kirjoitettu pyöreä nollasumma katkaisee arjen tasaisen kulun. Kaupan sosiaaliseen näyttämöön rakentuu uudenlainen suhde ja orientaatio.

Tämä tarina seuraa tanskalaisen Superflex-taiteilijaryhmän Free Shop -teoksen yksinkertaista juonta: "Kaikki, mitä asiakas haluaa ostaa, on ilmaista. Free Shop voi tapahtua missä tahansa, milloin tahansa, kenelle tahansa."

Superflex kertoo leikkivänsä ajatuksella vastataloudesta; sillä, että rahajärjestelmä olisikin erilainen. Siten Free Shop tuo osallistavan taiteen tarkasteluun erityisesti rahan välittämät ihmis- ja esinesuhteet. Ja tässä suhteiden tarkastelussa erityisen keskeisen roolin saa intervention taideluonteen paljastava nollahintainen ostoskuitti.

Osallistavaa taidetta on luonnehdittu usein perusta- vanlaatuisena käännöksenä taide-esineistä ihmisiin. Tämä käännös on merkinnyt sosiaalisten suhteiden korostamisen ohella aineellisen todellisuuden unohtamista tai vähintäänkin sen ohi katsomista. Siksi Free Shopin yhteydessä palautan taiteen tarkasteluun arkiset esineet ja asiat, ja erityisesti niiden merki- tyksen ihmistenvälisten suhteiden mahdollistajina ja välittäjinä.

IImainen aamiaiskahvi tai ilmainen kauppaostos katkaisee rahan kautta määrittyvän arjen ennakoivuuden: tuttu muuttuukin toiseksi ja vieraaksi. Sama

Kuva 4. Superflex 2011. Free Shop (Levykauppa Digelius, Helsinki). Kuva: IHME-nykytaidefestivaali/Veikko Somerpuro.

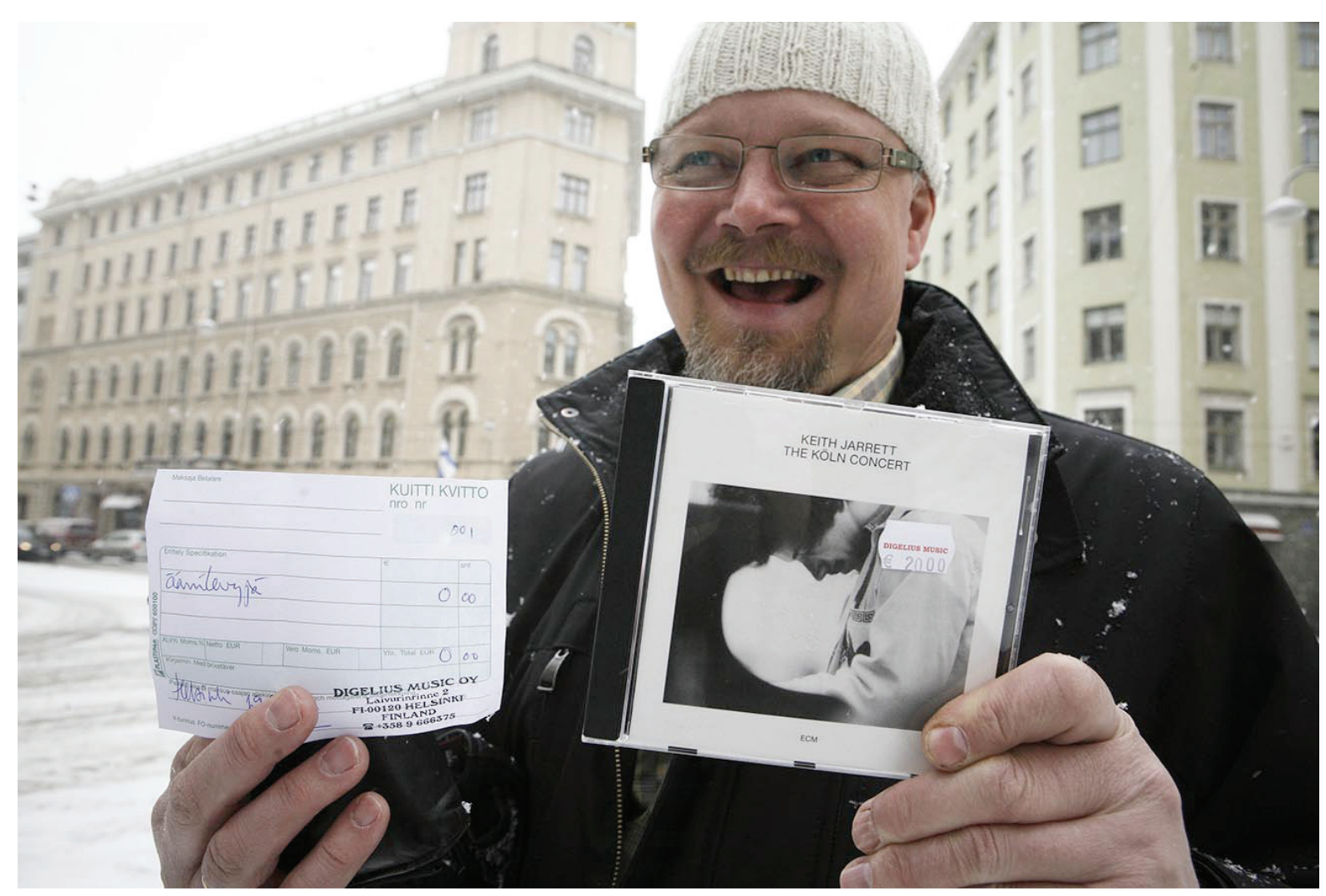


ajatus tutusta vieraana tulee esiin myös tässä kuvassa. Kyseessä on sisäänkäynti taiteilijapariskunnan Henriette Heisen ja Jakob Jakobsenin kotiin Kööpenhaminassa, ja samalla heidän perustamaansa ja vuosina 2001-2007 toimineeseen yliopistoon. Paikka, kerrostalon rappukäytävä, ei silti sovi perinteisiin mielikuviin yliopistosta. Jotain puuttuu, ja sen puuttuminen on tarkoituksellista (kuvat 5 ja 6).

Heise ja Jakobsen kuvailevat, kuinka CFU eli Copenhagen Free University syntyi, kun "Patjasta tuli residenssi, makuuhuoneesta elokuvateatteri, olohuoneesta kohtaamispaikka ja työhuoneesta arkisto, asunnostamme tuli yliopisto". Nimeämällä kotinsa yliopistoksi he halusivat palauttaa yliopiston lähemmäs sen alkuperäistä tehtävää. Opetuksen tuli pohjautua yhteisiin keskusteluihin ja tiedon yhteiseen ja vapaaseen jakamiseen.

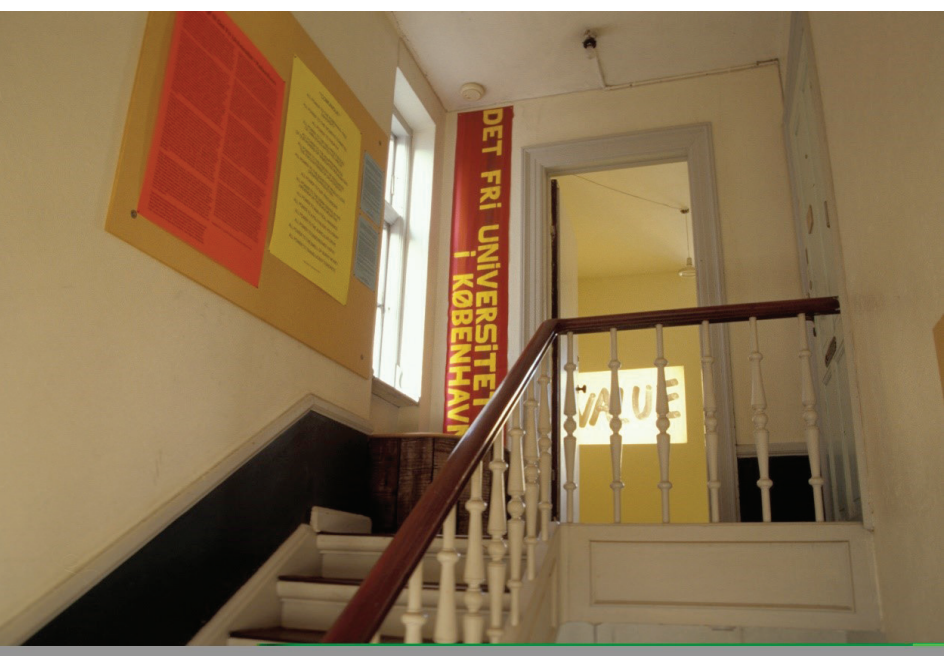

Copenhagen Free Universityn instituutiokriittisessä toiminnassa aktivoituivat erityisesti kysymykset tiedosta, tietämättömyydestä ja representaatiosta. CFU:n tee-se-itse -aktivismi syntyi Tanskassa poliittiseen ilmastoon, jossa muukalaisvihamielisyyden ja rasismin kasvaessa puhuttiin suvaitsevaisen hyvinvointivaltiomallin epäonnistumisesta. CFU:n mukaan oli välttämätöntä perustaa uusia itsenäisiä instituutioita ja luoda vaihtoehtoista poliittista kieltä, poetiikkaa.

Myös CFU:n toiminta pohjasi radikaaliin vieraanvaraisuuteen. Se käytännössä oli vieraan - tuntemattoman ja tietämättömän - varassa. Tämä vieraus CFU:n yliopistotoiminnassa osoitti radikaalin puolensa viimeistään vuonna 2010, vuosia toiminnan lopettamisen jälkeen. Yliopisto sai Tanskan opetusministeriöltä kirjeen, jossa kiellettiin yliopisto-sanan käyttö osana CFU:n toimintaa "opiskelijoiden pettymysten" ehkäisemiseksi.

"Seuraavaksi juodaan Atlantin valtameri tyhjäksi, tai sulatetaan Antarktis tai maalataan taivas". Näin suunnitteli yksi tässä kuvassa kohti hiekkadyynin huippua etenevistä valkoisista pisteistä. Hän osallistui lapio kädessään satojen muiden vapaaehtoisten opiskelijoiden tavoin belgialaisen taiteilijan Francis Alÿsin suureen maansiirto-operaatioon, When Faith Moves

\section{Kuva 5. Copenhagen Free Universityn por-} raskäytävä 2001-2007. Kuva: CFU.

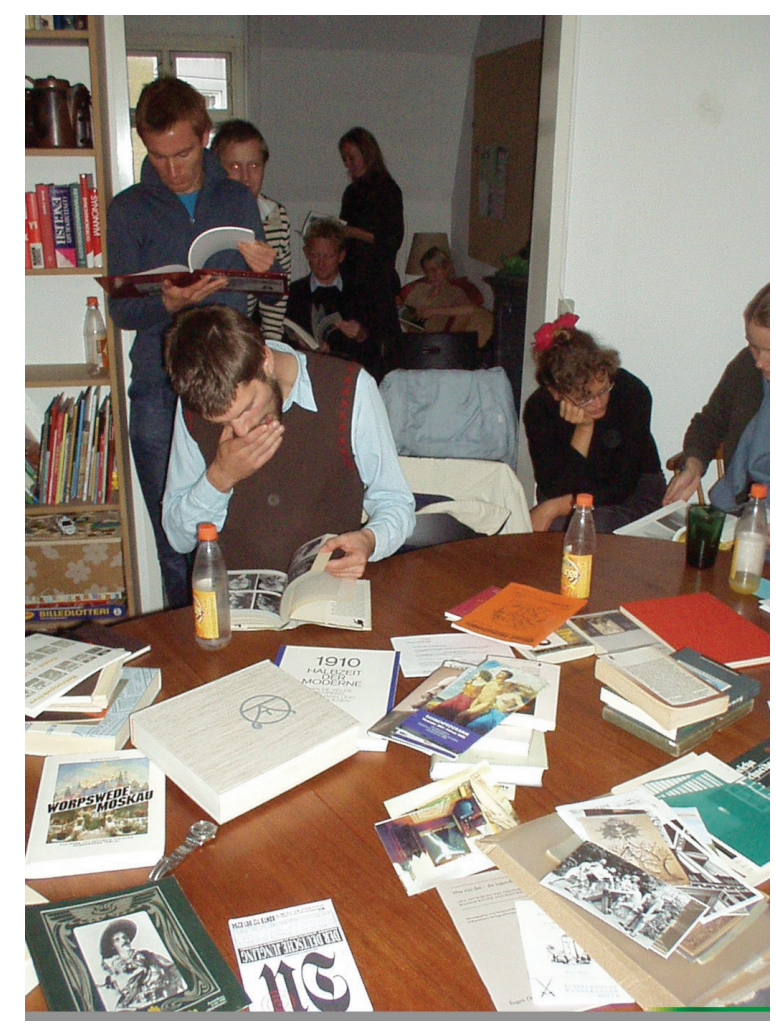

Kuva 6. Reform Event (Reformi-tapahtuma) Stefan Dillemuthin johdolla CFU:ssa 2002. Kuva: CFU.

Mountains -teokseen Perun pääkaupungin, Liman laitamilla vuonna 2002. Tarkoituksena oli siirtää - uskon voimalla ja raa'alla lapiotyöllä - kuvan hiekkadyyniä kymmenisen senttimetriä alkuperäiseltä paikaltaan. Antarktiksen sulattamisen kaltaiset uudet hankeideat 
osoittavat, kuinka taide saattaa saada ajattelemaan asioita, joita ei muutoin ajattelisi; huomaamaan asioita ja inmisiä, joita ei muutoin huomaisi. When Faith Moves Mountains -teoksen luennan lähtökohtana on utooppinen prosessi, jossa maiseman suureellisen, mutta ilmiselvästi hyödyttömän muokkauksen myötä synnytetään hetkellinen keskiö, 'katedraali', joka avaa tilaa yhteisöllisyydelle ja yhteisölliselle kuvittelulle.

Samalla se uudelleenaktivoi neuvottelun tilasta, omistussuhteista ja hyödystä: hiekkadyynin lapioiminen tuo esiin jättömaan arvottavan poliittisuuden.

Yksi tutkimukseni päätelmiä yhdistävä teema on vastikkeeton jakaminen. Ateria ja kauppaostokset saadaan ilmaiseksi; ilmaiseksi tarjotaan myös koulutusta, paikkaa valotaulussa, työvoimaa ja neuvonantoja. Kun ihmisten välisistä suhteista poistetaan raha ja vaihdantatalouden periaatteet, tilalle nousee ajatus radikaalista vieraanvaraisuudesta: lahjasta joka ei edellytä vastalahjaa.

Tämänkaltainen lahja toimii vastakkaisella logiikalla kuin hyöty- ja tuloskeskeinen ajattelu. Siksi sen prosessit voivat aktivoida ja purkaa inmisten ja yhteiskunnan luomia raja-aitoja. Tällöin osallistava taide voi synnyttää toisin kuvittelemista ja toisin olemista - arkipäivän utopioita, joissa jotain puuttuu.

Jotain puuttuu, minkä myös arvoisa vastaväittäjäni väitöstutkimuksestani pian viisain sanankääntein varmasti osoittaa. Ja se on hyvä. Enemmän kuin tutkimuksellista eheyttä toivon, että väitöstyöhöni on jäänyt riittävästi avoimuutta ja huokoisuutta, johon tarttua ja josta käsin tarkastella myös sen sisältöjä toisin. Vain siten nousee aito kriittisyys. Ja vain siten ajatus jonkun puuttumisesta kääntyy uuden tiedon mahdollisuudeksi.

FT, KK Riikka Haapalaisen taidehistorian väitöstutkimus Utopioiden arkipäivää. Osallistumisen ja muutoksen paikkoja nykytaiteessa 1980-2011 tarkastettiin Helsingin yliopistossa tammikuussa 2018.

Vastaväittäjänä toimi dosentti yliopistonlehtori Leena-Maija Rossi (Lapin yliopisto). 